\title{
Comparative Advantage of Siamese Orange (Citrus Nobilis) Farming in District of 50 City, West Sumatera
}

\section{Mustopa Romdhon*, Apri Andani, and Wahyu Fitri Nasari}

Department of Agricultural Socio-economics, Faculty of Agriculture University of Bengkulu *Email address: abyaz79@yahoo.co.id

\begin{abstract}
Citrus Nobilis, known as Siamese Orange, is one of the strategic fruits commodities for West Sumatera because of its high productivity, approximately $6-9$ tons per hectare. However, this commodity faces a fluctuated demand both in domestic and international markets. This is a serious problem due to its impact on farm income as well as in its comparative advantage. The aim of this study was to analyze the comparative advantage level of siamese orange farming. Eighty four Siamese Orange farmers are selected using simple random sampling to get orange farming data. The comparative advantage level is measured with Policy Analysis Matrix (PAM) approach. The results show that siamaese orange farming has a high comparative advantage, indicating by more than zero value of social profitability and less than one domestic resource cost ratio. This comparative advantage could be sustained if domestic resources are efficiently utilized through the improvement of labor skills and the use of Siamaese Orange farming modern technology.
\end{abstract}

Keywords: Comparative advantage, siamese orange farming, PAM

Citation to this paper should be made as follows :

Romdhon, M. M., A. Andani, and W. F. Nasari. 2018. Comparative advantage of Siamese Orange (Citrus

Nobilis) Farming in District of 50 Kota, West Sumatera. Agritropica: Journal of Agricultural Science. 1 (2): 62-67. DOI: https://doi.org/10.31186/J.Agritropica.1.2.62-67

\section{INTRODUCTION}

Siamese Orange is the main local commodity of Lima Puluh Kota District, with productivity range from 6 to 9 tons/ha and total land area of 570.89 ha in Gunung Omeh Sub district (Dinas Pertanian Sumbar, 2015). Siamese Orange production in this area is marketed to Sumatra, Java and abroad such as Malaysia. The current transportation infrastructure has facilitated the flow of Siamese Orange to Padang City through Teluk Bayur Port and Minangkabau International Airport. However, in 2006-2015, the export of Siamese Orange decreased due to the unstable economic condition. Meanwhile, the competition in the global horticultural commodity market is getting tighter, which in turn affects the competitiveness of Siamese orange produced in Gunung Omeh sub district. Those Impact on small niche market occupation and farm income

Farming competitiveness is defined as the ability of producers to produce a commodity with a relatively low cost so that prices in the international market is profitable (Novianti, 2003). The commodity competitiveness can be measured with the comparative advantage indicators, such as the labor and land productivity. According to the Asian Development Bank (1992 in Aprizal, 2013), the comparative advantage is the ability of a region to produce with a relatively low cost. Comparative advantage can also be measured with the social value of cost of production by using the shadow price of input and output. Dewanata (2011) shows that exchange rate changes have greater effect on the Siamese Oranges with modern technology than that with traditional technology in Garut 
Regency. In addition exchange rate, output price, and price of subsidized fertilizer also significantly influence impact farm profit. The results of Wiji (2007) indicate that the Siamese farming system in Pontianak is highly competitive so that it's commodity produce can compete in the international market and be able to finance its domestic cost. Sayekti (2011) and Husaini (2012) also concluded that Siamese Orange farming has both competitive and comparative advantages.

This study focuses on the comparative advantage of Siamese orange farming in the highlands compared to previous researchs which analyzed the comparative competitiveness of Siam Orange Farming in lowland and Agroclimate Differences (Husaini, 2010), Differences in Production Technology (Dewanata, 2011), and Feasibility and Competitiveness business. This study aims to analyze the comparative competitiveness of Siamese Orange Farming in Kanagarian Koto Tinggi District of Gunung Omeh Disctrict of 50 Kota West Sumatera. The results of this study are expected to provide an overview of Siamese Orange farming competitiveness for decision makig in order to design policies for Siamese orange agribusiness development in Kanagarian Koto Tinggi District of Gunung Omeh District of 50 Kota West Barat.

\section{RESEARCH METHODS}

This research was conducted in Kanagarian Koto Tinggi of Gunung Omeh Subdistrict, Lima Puluh City, West Sumatera Province, which is the largest production center of Siamese Orange. 84 Siamese Orange farmers are selected using Simple Random Sampling to collect data on farm cost, production quantity and selling price, fertilizer distribution cost, export, the shadow price of input and output. Assumptions used in the analysis include: (a) Rp 13.450 of USD-IDR, (b) $6.28 \%$ of inflation rate, and (c) $12.5 \%$ of interest rate. Input and output are set at two types of price, namely private price and shadow price. The private price is determined at the output market price or the price of the paid production inputs. The shadow price, according to Gitingger (1986), is the inputs' and outputs' prices that occur in the perfectly competitive market and equilibrium condition. The price is determined on the basis of prevailing market prices. The shadow price of the tradable production inputs equals the shadow output price, i.e., the FOB (Free On Board) price and for the imported commodities using the CIF (Cost Insurance Freight) price. The shadow price of non-tradable production inputs using the prevailing domestic price in the research area.

Data analysis method used is Policy Analysis Matrix (PAM) (Monke and Pearson, 1989; 2003). The PAM model has also been applied to analyse the profitability and competitiveness of Bengkulu Lobster, by Sukiyono (2011). The comparative competitiveness from private profits and the ratio of private costs with PAM Model can be calculated as follows:

Table 1. Comparative advantage calculation with PAM Model

\begin{tabular}{|c|c|c|c|c|}
\hline \multirow[b]{2}{*}{ Decription } & \multirow[b]{2}{*}{ Revenue } & \multicolumn{2}{|c|}{ Costs } & \multirow[t]{2}{*}{ Profits } \\
\hline & & Tradable & $\begin{array}{c}\text { Non- } \\
\text { tradable }\end{array}$ & \\
\hline $\begin{array}{l}\text { Private } \\
\text { Price }\end{array}$ & A & B & $\mathrm{C}$ & $\mathrm{D}$ \\
\hline Social Price & $\mathrm{E}$ & $\mathrm{F}$ & G & $\mathrm{H}$ \\
\hline Divergence & $\mathrm{I}=\mathrm{A}-\mathrm{E}$ & $\mathrm{J}=\mathrm{B}-\mathrm{F}$ & $\mathrm{K}=\mathrm{C}-\mathrm{G}$ & $\mathrm{L}=\mathrm{I}-\mathrm{J}-\mathrm{K}$ \\
\hline
\end{tabular}

Sumber: Monke and Pearson, 1989

where is: (A) farm revenue based on private price, (E) revenue based on social price, (I) output transfers, (B) tradable input cost based on private price, $(\mathrm{F})$ tradable input cost based on social price, (J) input transfers, (C) domestic input cost based on market price, $(G)$ domestic input cost based on social price, $(\mathrm{K})$ factor transfers, (D) private profits, $(\mathrm{H})$ social profits, $(\mathrm{L})$ net transfers.

The criteria of comparative advantage of Siam Gunung Omeh citrus farming are:

1. Social Profit (SP) i.e., $\mathrm{H}=\mathrm{E}-(\mathrm{F}+\mathrm{G})$. Social profit is an indicator of comparative advantage. If $\mathrm{H}>0$ then the farm is worth 
developing. Conversely, if $\mathrm{H} \leq 0$, it means that commodities cannot compete without or intervene by the government.

2. Domestic Resource Cost Ratio (DRCR). If DRCR $<1$, then the commodity system has a comparative advantage, which means the commodity exploitation has an efficient. Conversely, if DRCR $\geq 1$, the commodity system does not have a comparative advantage, meaning that commodity exploitation does not have efficiency

\section{RESULTS AND DISCUSSION}

The results show that tradable input costs are greater than those of non-tradable. Tradable input costs are dominated by the cost of importing fertilizers, pesticides, and fuels, while non-tradable inputs are dominated by labor, land and local fertilizers. Labor inputs are low mobility due to its local skills. The study also indicates that the input market of Siamese orange production in research area connects to output and input international market as an example pesticide is an importing inputs from multinational company. Their market covers all agricultural countries all over the world, and the product price is also dollars standards. Since, the price of product when It was imported to Indonesia based on the CIF (Cost Insurance Freight) price as presented in Appendix 1.

The comparative competitiveness of orange farming system in the global market or not can be examined from the structure of tradable and non-tradable input costs. The PAM results indicated that orange farming in Kanagarian Koto Tinggi, has a comparative advantage characterized by Domestic Resource
Cost Ratio (DRCR) and Social Profits (PS) as presented in Table 1.

The DRCR value of Siamese Orange Farm in Kanagarian Koto Tinggi is 0.11. The value indicates that to profit US $\$ 100$, farmers must spend the cost for domestic resource approxemately US $\$ 11$. In terms of trade in the international market, the 0.11 value of DRCR indicates the high comparative advantage ( 0 to $\leq 1$ ) of Siamese orange farming. The lower the DRCR value, the higher the comparative advantage of the Siamese orange farm in Kanagarian Koto Tinggi. This result also informs that this farming is able to survive even without government intervention. The reason is that this farming has the necessary domestic resources (i.e. land) for its development. The high comparative advantage is supported by suitable land and climate conditions for orange farming and the abundance of labour for a more efficient utilization of domestic resources. This value also indicates that efficiency of domestic resources used (i.e. labour and fertilizers) will have a comparative advantage. This conclusion is also supported by the value of PS, i.e., $\operatorname{Rp} 439,166,360 / \mathrm{Ha} / Y e a r$. The social profits (PS) are gained in perfectly competitive markets, when there is no government policy intervention and market failures in the form of subsidies on production inputs, particularly production of tradable inputs.

The comparative advantage of Siamese Orange in Kanagarian Koto Tinggi is higher than the Garut Orange (Dewanata,2011), the Pontianak Siamese Orange (Wiji, 2007), and Sambas Siamese Orange with DRCR 0.70, 0.17 and 0.15 , respectively.

Tabel 2. Comparative advantage of siamese orange

\begin{tabular}{lrrrr}
\hline \multirow{2}{*}{ Decription } & Farm revenue & \multicolumn{2}{c}{ Input Costs (Rp) } & \multicolumn{1}{c}{ Profits } \\
\cline { 3 - 4 } & \multicolumn{1}{c}{$(\mathrm{Rp})$} & \multicolumn{1}{c}{ Tradable } & Non Tradable & \multicolumn{1}{c}{$(\mathrm{Rp})$} \\
\hline Private Price & $279,747,024$ & $87,810,597$ & $38,272,566$ & $153,663,861$ \\
Social Price & $591,479,722$ & $100,084,882$ & $52,228,480$ & $439,166,360$ \\
Policy Impacts & $(311,732,698)$ & $(12,274,285)$ & $(13,955,914)$ & $(285,502,499)$ \\
PS & & & & $439,166,360$ \\
DRCR & & & & 0,11 \\
\hline
\end{tabular}

64 | Romdhon et al : Comparative Advantage of Siamese Orange (Citrus Nobilis) Farming in ... 
However, the Siamese orange comparative advantage in Kanagarian Koto Tinggi is lower than those in Jember Regency, in which DRCR only 0.05. Orange farmers in Jember District allocate and utilize domestic resources more efficiently.

In general, the comparative advantage of Siamese orange farming in Kanagarian Koto Tinggi is higher, as also found in a number of orange centres in Indonesia. This high comparative advantage is due to the abundance of domestic resources, particularly non-tradable inputs such as labour, land, and suitable agro-climate. However, the efficiency of domestic resources such as labour and land needs to be improved. This is to anticipate the increase of labor cost and land rent in Kanagarian Koto Tinggi due to competition of labour and land use with other commodity farming (Romdhon, 2004). Efforts can be done by improving management skills of Koto Tinggi's Siamese orange farmers. The introduction of modern technology in Siamese orange farming in Jember District could improve competitiveness of Siamese orange. The support of farming infrastructure (farm road) can also optimize efficiency of domestic resource utilization so the cost of input and output transport can be minimized. Farmers can directly deliver their products to large collectors or exporters, so they can gain a maximum of twice the profit gained today. This effort will increase Siamese orange export, as the competitiveness of Indonesian orange exports compared to three ASEAN countries (Malaysia, Philippines, and Thailand), is lower in the international market (Hanani, 2009).

\section{POLICY IMPLICATIONS}

Siamese Orange farming system in Kanagarian Koto Tinggi has a high comparative advantage and efficiency in domestic resources utilization as indicated by the private profits and social benefits. The policy should be implemented for sustaining the comparative advantage was the improvement of labor skills, and the use of postharvest modern technology.

\section{REFERENCE}

Aprizal. 2013. Analisis Daya Saing Usaha Tani Kelapa Sawit Kabupaten Mukomuko. Jurnal AGRISEP. 12(2):133 - 146.

Dewanata.O.P 2011. Analisis Daya Saing dan Dampak Kebijakan Pemerintah Terhadap Komoditas Jeruk Siam di Kabupaten Garut [Skripsi]. Departemen Agribinis Fakultas Ekonomi dan Manajemen, Institut Pertanian Bogor, Bogor.

Dinas Pertanian Tanaman Pangan dan holtikultura Provinsi Sumatera barat, 2008. Tanaman Holtikultura (http:/ / diperta.sumbarprov.go.id/) diakses tanggal 16 September 2015.

Gittingger,J.P.1986. Analisis Ekonomi ProyekProyek Pertanian. UI-Press.Jakarta.

Hanani, N. 2009. Analisis Tingkat Daya Saing Ekspor Buah-Buahan Indonesia. Jurnal AGRISE, IX(1):1-8

Husaini. M. 2012. Pengkajian Daya Saing dan Dampak Kebijakan Terhadap Usahatani Padi dan Jeruk Lahan Gambut Kabupaten Barito Kuala Kalimantan Selatan. Jurnal Agribisnis Pedesaan, Volume 02:122-143 Universitas Lambung Mangkurat, Banjar Baru.

Monke, E. A., And E. S. Pearson. 1989. The Policy Analysis Matrix for Agricultural Development. Cornel University Press, London.

Monografi Kanagarian Koto Tinggi. 2014. Profil Kanagarian Koto Tinggi. Kanagarian Koto Tinggi.

Novianti, T. 2003. Analisis Dampak Kebijakan Pemerintah Terhadap Daya Saing Komoditas Unggulan Sayuran. [Tesis]. Program Pasca Sarjana. Institut Pertanian Bogor. Bogor.

Pearson, S., C. Gotsch dan S. Bahri. 2003. Aplikasi Policy Analysis Matrix pada Pertanian Indonesia. Grafika Mardi Yuana, Bogor. 
Romdhon, M. M. dan I. Cahyadinata. 2004. The Competitiveness and Efficiency of Rice Farming System at North Bengkulu, Bengkulu Province. https://web.stanford.edu/group/FRI/in donesia/research/bengkulurice.pdf. accessed on 10th March 2018.

Sayekti, Aprila Laila and Zamzani, Lizia.2011Analisis Keunggulan Komparatif dan Kompetitif Jeruk Siam di Sentra Produksi. Jurnal Widyariset 14(1):1-10. Puslitbang Hortikultura. Jakarta

Sukiyono, Ketut. 2011. Analisa Keuntungan dan Daya Saing Kompetitif Dan
Komparatif Komiditi Lobster Di Provinsi Bengkulu: Aplikasi Model PAM. Paper presented at National Seminar on Peran IPTEK untuk Mengantisipasi Perubahan Iklim dalam PerspePStif Pertanian Berkelanjutan, 23-25 Mei 2011, Fakultas Pertanian Universitas Sriwijaya, Palaembang. Prosiding Semirata Bidang Ilmu-ilmu Pertanian BPS-PTN Wilayah Barat Tahun 2011. ISBN :978-979-8389-184.

Wiji, 2007. Analisis pengembangan Sentra Jeruk Siam Pontianak di Provinsi Kalimantan Barat (Tesis). Sekolah Pascasarjana, Institut Pertanian Bogor, Bogor. 
Appendix 1. Private and economic analyses of Citrus Nobilis Farming at Kanagarian Koto TinggiWest Sumatera

\begin{tabular}{|c|c|c|c|c|c|c|c|}
\hline \multirow{2}{*}{ Description } & \multirow{2}{*}{ unit } & \multirow{2}{*}{ Volume } & \multirow{2}{*}{$\begin{array}{l}\text { Mean } \\
\text { per ha }\end{array}$} & \multicolumn{2}{|c|}{ Private (Rp) } & \multicolumn{2}{|c|}{ Social (Rp) } \\
\hline & & & & Price & cost & price & cost \\
\hline Output & $\mathrm{Kg}$ & $1,563,333$ & 18,611 & 15,030 & $79,747,024$ & 31,781 & $591,479,722$ \\
\hline \multicolumn{8}{|l|}{ Input Tradable } \\
\hline Urea & $\mathrm{Kg}$ & 50,070 & 596 & 5,000 & $9,075,902$ & 5,386 & $9,784,239$ \\
\hline TSP & $\mathrm{Kg}$ & 40,404 & 481 & 7,500 & $10,789,637$ & 10,623 & $15,450,724$ \\
\hline $\mathrm{KCl}$ & $\mathrm{Kg}$ & 48,811 & 581 & 15,000 & $25,714,107$ & 16,727 & $29,043,433$ \\
\hline $\mathrm{Za}$ & $\mathrm{Kg}$ & 42,529 & 506 & 5,000 & $7,392,798$ & 6,265 & $9,440,341$ \\
\hline Ponska & $\mathrm{Kg}$ & 36,993 & 440 & 2,952 & $4,613,226$ & 6,265 & $7,029,100$ \\
\hline NPK Mutiara & $\mathrm{Kg}$ & 28,209 & 336 & 2,500 & $5,323,274$ & 7,260 & $3,831,243$ \\
\hline \multicolumn{8}{|l|}{ Pesticide } \\
\hline Alika & Litre & 36 & 0 & 519,881 & $5,258,520$ & 519,881 & $5,258,520$ \\
\hline Score & Litre & 19 & 0 & 667,679 & $3,927,752$ & 667,679 & $3,927,752$ \\
\hline Marshal & Litre & 6 & 0 & 47,560 & 279,629 & 47,560 & 279,629 \\
\hline Atonik & Litre & 3 & 0 & 26,190 & 78,952 & 26,190 & 78,952 \\
\hline Agrimax & $\mathrm{Kg}$ & 4 & 0 & 496,429 & $1,813,810$ & 496,429 & $1,813,810$ \\
\hline Lanate & $\mathrm{Kg}$ & 131 & 2 & 177,321 & $8,780,886$ & 177,321 & $8,780,886$ \\
\hline Sinon 45 & $\mathrm{Kg}$ & 76 & 1 & 109,268 & $3,170,867$ & 109,268 & $3,170,867$ \\
\hline gasoline & Litre & 633 & 8 & 8,000 & $1,591,238$ & 10,800 & $2,195,387$ \\
\hline Total Tradable c & & 247,925 & 2,951 & $2,090,280$ & $87,810,597$ & $2,107,653$ & $100,084,882$ \\
\hline \multicolumn{8}{|c|}{ Input Non Tradable } \\
\hline Seed & stem & 21,300 & 254 & - & - & 12,000 & $4,800,000$ \\
\hline Organ.Fertilizer & $\mathrm{Kg}$ & $2,085,333$ & 24,825 & 249 & $6,349,206$ & 249 & $6,349,206$ \\
\hline \multicolumn{8}{|l|}{ Family labour } \\
\hline Fertilization & day & 902 & 11 & 50,357 & $2,589,747$ & 50,357 & $2,589,747$ \\
\hline Weeding & day & 977 & 12 & 58,215 & $4,032,889$ & 58,215 & $4,032,889$ \\
\hline Spraying & day & 413 & 5 & 50,238 & $9,445,595$ & 50,238 & $9,445,595$ \\
\hline Harvest & day & 186 & 2 & 50,000 & $3,636,190$ & 50,000 & $3,636,190$ \\
\hline Maintenance & day & 123 & 1 & 31,548 & $1,827,560$ & 31,548 & $1,827,560$ \\
\hline \multicolumn{8}{|c|}{ Non-family labour } \\
\hline Fertilization & day & 269 & 3 & 50,357 & 936,146 & 50,357 & 936,146 \\
\hline Weeding & day & 233 & 3 & 54,583 & $1,159,457$ & 54,583 & $1,159,457$ \\
\hline Spraying & day & 100 & 1 & 50,357 & $3,244,357$ & 50,357 & $3,244,357$ \\
\hline Harvest & day & 90 & 1 & 50,119 & $1,858,937$ & 50,119 & $1,858,937$ \\
\hline Maintenance & day & 79 & 1 & 46,548 & $1,284,381$ & 46,548 & $1,284,381$ \\
\hline Hoe & Unit & 133 & 2 & 47,798 & 59,482 & 47,798 & 59,482 \\
\hline Cleaver & Unit & 85 & 1 & 38,690 & 36,780 & 38,690 & 36,780 \\
\hline Handsprayer & Unit & 88 & 1 & 319,464 & 210,617 & 319,464 & 210,617 \\
\hline Scissor & Unit & 267 & 3 & 51,429 & 166,090 & 51,429 & 166,090 \\
\hline Basket & Unit & 262 & 3 & 106,071 & 137,500 & 106,071 & 137,500 \\
\hline Kibang & Unit & 288 & 3 & 54,167 & 57,442 & 54,167 & 57,442 \\
\hline Drum & Unit & 106 & 1 & 140,952 & 112,880 & 140,952 & 112,880 \\
\hline $\begin{array}{l}\text { Grass-cutting } \\
\text { machine }\end{array}$ & Unit & 54 & 1 & 683,333 & 287,411 & 683,333 & 287,411 \\
\hline Sancin & Unit & 41 & 0 & $2,283,333$ & 697,161 & $2,283,333$ & 697,161 \\
\hline fruit basket & Unit & 287 & 3 & 102,738 & 35,465 & 102,738 & 35,465 \\
\hline Scoop & Unit & 77 & 1 & 11,268 & 9,212 & 11,268 & 9,212 \\
\hline Land & Hectare & 1 & 2 & & & $14,687,500$ & $9,255,319$ \\
\hline Tax & year & 53 & 1 & 5,031 & 99,405 & - & \\
\hline \multicolumn{2}{|c|}{ Total Non-tradable cost } & $2,111,748$ & 25,142 & $4,336,845$ & $38,272,566$ & $19,031,314$ & $52,228,480$ \\
\hline \multicolumn{2}{|l|}{ Total cost } & & & & $126,083,163$ & & $52,313,362$ \\
\hline \multicolumn{2}{|l|}{ Profit } & & & & $153,663,861$ & & $439,166,360$ \\
\hline
\end{tabular}

